\title{
Laying the foundation for the Galileo myth
}

\section{Stefano Gattei: On the life of Galileo. Viviani's historical account and other early biographies. Princeton: Princeton University Press, 2019, Ixviii + 348 pp, € 43.33 HB}

\section{Matteo Valleriani ${ }^{1}$}

Accepted: 14 December 2020 / Published online: 5 January 2021

(c) The Author(s) 2021

Gattei's On the Life of Galileo is a collection of fourteen early biographies of Galileo Galilei, the first written around 1633 and the last in 1702. The author argues that these early biographies are historical sources that allow us to understand how the myth of Galileo was built over the centuries. His "pupils and followers" (x), in particular, are considered the primary myth makers. Of all the biographies, Gattei convincingly places particular weight on Vincenzo Viviani's Racconto istorico, written in 1654 but first published in 1717, as this short biography served as a model for later ones.

As mentioned, however, there are documents dated earlier than Viviani's. In Gattei's words, "the shaping of the Galileo myth started much earlier" (xi). He is referring to two short biographies that were both written in 1633, not at all an annus mirabilis for Galileo, being the year the famous abjuration took place. Before entering into the details, though, I would like to give a wider interpretation to the phrase we just cited from Gattei.

This work is addressed to those who are well-acquainted with the figure of Galileo. If this book were to serve as an introduction to someone with little or no prior knowledge of Galileo, the reader would not learn why historians consider Galileo's work and life as fundamental to understanding the course of modern of science in the Western world, not to mention many other domains of knowledge and aspects of society. The myth of Galileo primarily emerged because of his work and only then the biographical efforts of his disciples. To fully appreciate Gattei's efforts, therefore, the reader unfamiliar with the figure of Galileo should read at least one other biography, not a historical but a contemporary one. John Heilbron's Galileo (2010) is the perfect starting point.

Matteo Valleriani

valleriani@mpiwg-berlin.mpg.de

1 Technische Universität Berlin, Max Planck Institute for the History of Science, Tel Aviv University, Boltzmannstr. 22, 14195 Berlin, Germany 
The myth of Galileo has been based on different aspects of his work: the musical theory of his father (Boschiero 2018), his telescopic discoveries (Bucciantini et al. 2012), his artistic talent (Bredekamp 2014), his social skills (Biagioli 1993, 2006), his ingenuity in mechanics (Renn et al. 2001; Büttner 2019), his polemic verve (Besomi and Helbing 2005), his "affair" (Finocchiaro 1989; Feldhay 1995), and even the work of other thinkers with similar projects (Schemmel 2008). These are only a few of the many aspects of Galileo's life on which his myth was built, a myth so powerful that it has been used politically to support freedom fighters and democracy in recent years (Nenci 2009).

The oldest biographies analyzed in this volume, those produced in 1633, are by Girolamo Ghilini and Leo Allatius. Needless to say, these documents have been highly neglected until now, despite the fact that their date is so special. Ghilini's short biographical "entry" for a "Theater of Illustrious Men" makes no apparent attempt to deeply characterize Galileo. Allatius' biography is decisively more interesting. This biography was going to the press when its author received the news of the abjuration. Gattei uses solid and meticulous archival research-which is evident throughout this volume - to show how Allatius, with lightning-fast action, changed his approach from emphatic to one that can be described as obscurantist. In the revised version, Allatius notably left the Saggiatore in the list of mentioned works, though nowadays this work is often considered to be the reason that his relationship with the Jesuits and the Roman curia began to deteriorate.

As mentioned, special attention is given to Viviani's biography, which is concomitantly discussed with Niccolò Gherardini's work. While this historical source achieved great influence, it is also noteworthy due to the fact that, with this biography, Viviani consciously tried to restore Galileo's legacy. Viviani does not portray him as the hero of freedom of research but "as a Christian hero of science: restored to faith by the acknowledgement of his mistakes, purged by a sincere act of contrition, and intimately and fervently obedient to the Church" (xxv-xxvi).

Although a historical and theoretical chapter dedicated to the genre of biographies in the seventeenth and eighteenth century is missing, Gattei elaborates upon the subject, particularly in his analysis of Viviani's Racconto. According to the author, biographies belong to the literary genre rather than to the scholarly one. The aim is to "provide the reader with ethical models..." (xviii). On the basis of Gattei's collection, I would add that biographies were also written to provide the writer with specific institutional connections. Gattei's identification of Giorgio Vasari's Lives (1550) as the foundation of the genre that most significantly shaped Galileo's legacy is highly interesting and convincing.

The collection further includes the biographies of Gian Vittorio Rossi (1643); Vittorio Siri (1647), who first mentioned Galileo's Discorsi; Niccolò Gherardini (1654); Lorenzo Crasso (1666); Viviani's Report on Galileo's later works (1674); Isaac Bullart (1682), whose work made use of Rossi's and Crasso's works as sources; Joachim von Sandrart (1683); Paul Freher (1688), who explicitly used Ghilini's work; and Viviani's Testimony of a grateful soul (1702). The work concludes with an appendix that contains Maffeo Barberini's Adulatio perniciosa (Perilous Flattery) from 1620, a poem that emerged from Barberini's enthusiasm for Galileo's telescopic discoveries. In his introduction, Gattei also analyzes several 
incomplete biographical projects (by Martin Vogel, Thomas Salusbury, and Antonio Baldigiani, respectively) additional testimony to the author's impressive archival work.

With beautiful graphic design, the biographies are presented using facing pages in their original languages and in their English translation. The meticulous analytical work, however, is confined to a list of endnotes placed after each biography, which does not make the reading easier and leaves a lot of blank space. Gattei's philological and translation work is impeccable and the volume is completed by a rich apparatus as well as numerous historical illustrations. A gem in the editorial market on Galileo.

Funding Open Access funding enabled and organized by Projekt DEAL.

Open Access This article is licensed under a Creative Commons Attribution 4.0 International License, which permits use, sharing, adaptation, distribution and reproduction in any medium or format, as long as you give appropriate credit to the original author(s) and the source, provide a link to the Creative Commons licence, and indicate if changes were made. The images or other third party material in this article are included in the article's Creative Commons licence, unless indicated otherwise in a credit line to the material. If material is not included in the article's Creative Commons licence and your intended use is not permitted by statutory regulation or exceeds the permitted use, you will need to obtain permission directly from the copyright holder. To view a copy of this licence, visit http://creativecommons.org/licen ses/by/4.0/.

\section{References}

Besomi, Ottavio, and Mario Helbing (eds.). 2005. Il Saggiatore. Eidzione critica. Padova: Editrice Antenore.

Biagioli, Mario. 1993. Galileo courtier. Chicago: The University of Chicago Press.

Biagioli, Mario. 2006. Galileo's instruments of credit: Telescopes, images, secrecy. Chicago: University of Chicago Press.

Boschiero, Luciano. 2018. Galileo Galilei. The Tuscan Artist. Cham: Springer.

Bredekamp, Horst. 2014. Galileis denkende Hand. Form und Forschung um 1600. Berlin: De Gruyter.

Bucciantini, Massimo, Michele Camerota, and Franco Giudice. 2012. Il telescopio di Galileo. Una storia Europea. Torino: Giulio Einaudi Editore.

Büttner, Jochen. 2019. Swinging and Rolling: Unveiling Galileo's Unorthodox Path from a Challenging Problem to a New Science. Vol. 335 Boston Studies in the Philosophy and History of Science. Cham: Springer Nature.

Feldhay, Rivka. 1995. Galileo and the Church: Political inquisition or critical dialogue?. Cambridge: Cambridge University Press.

Finocchiaro, Maurice A. 1989. The Galileo affair. A documentary history. Berkeley: University of California Press.

Heilbron, John L. 2010. Galileo. Oxford: Oxford University Press.

Nenci, Elio. 2009. Glaubenshüter und Paladine der Vernunft. Der historiographische Streit um den Fall Galilei vom 17. bis zum 19. Jahrhundert. Sterne und Weltraum Dossier 1: 94-103.

Renn, Jürgen, Peter Damerow, and Simone Rieger. 2001. Hunting the white elephant. In Galileo in context: An engineer-scientist, artist, and courtier at the origins of classical science, ed. Jürgen Renn, 29-152. Cambridge: Cambridge University Press.

Schemmel, Matthias. 2008. The english Galileo: Thomas Harriot's work on motion as an example of preclassical mechanics. Dordrecht: Springer.

Publisher's Note Springer Nature remains neutral with regard to jurisdictional claims in published maps and institutional affiliations. 